\title{
CHARACTERIZATION OF ODOUR-ACTIVE VOLATILES AND SENSORY ANALYSES OF ROASTED OAK (Quercus humboldtii Bonpl.) ACORNS, A COFFEE SUBSTITUTE
}

\author{
CARACTERIZACIÓN DE LOS COMPUESTOS ACTIVOS OLFATIVAMENTE Y ANÁLISIS \\ SENSORIAL DE LOS FRUTOS TOSTADOS DEL ROBLE (Quercus humboldtii Bonpl.), \\ COMO UNA BEBIDA SUSTITUTA DE CAFÉ
}

\begin{abstract}
Liseth DÍAZ-ROJAS ${ }^{1}$, Nathaly GALÁN-BERNAL ${ }^{1}$, Diana Paola FORERO, Dr. Sc ${ }^{2}$ Edgar Leonardo LINARES ${ }^{3}$, Juan Camilo MARÍN-LOAIZA, Dr. Sc. ${ }^{1}$, Coralia OSORIO, Dr. Sc. ${ }^{2 \star}$
\end{abstract}

Received: November 29, 2018. Approved: April 22, 2019

\begin{abstract}
Background: Oak acorns are roasted and grounded to produce a powder that is used to prepare a coffee substitute beverage. Objective: To identify the odour-active volatiles of the powder derived from roasted acorns of Quercus humboldtii and to perform a quantitative descriptive analysis (QDA) of its appearance, odour, and taste. Methods: The odour-active volatiles of roasted oak acorn powder were extracted by SDE and analyzed by GC/MS and olfactory analyses (GC/O). Sensorial analyses of this beverage were done by QDA (Quantitative Descriptive Analysis). Results: Nineteen compounds were identified, showing acid, buttery/caramel, smoke/roasted, and fruity odour notes, which are common to those of roasted coffee. Ketones, aldehydes, aliphatic acids, furanic alcohols and pyrazines were identified as relevant for this coffee substitute beverage. The major volatile compounds were furfural, 5-methyl furfural, furfuryl alcohol, and 3-hydroxy-2-butanone, some of them related to the sugar breakdown by heating. Odour attributes characterized by QDA, were in agreement with those detected by GC-O (Gas Chromatography coupled to Olfactometry), but some off-taste notes were detected. Conclusions: The results of molecular sensory approach confirmed that this product resembles coffee; however, QDA analyses showed the presence of undesirable taste. More studies are needed in order to improve the taste quality of this coffee substitute.
\end{abstract}

Keywords: SDE; QDA; odour-active volatiles; gas chromatography; food chemistry.

\section{RESUMEN}

Antecedentes: los frutos del roble se tuestan y muelen para producir un polvo que es empleado en la preparación de una bebida sustituta del café. Objetivos: identificar los compuestos volátiles activos olfativamente presentes en el polvo proveniente de los frutos tostados de Quercus humboldtii; así como llevar a cabo un análisis cuantitativo descriptivo (QDA) de la apariencia, olor y sabor de este polvo. Métodos:

\footnotetext{
Departamento de Farmacia. Universidad Nacional de Colombia-Sede Bogotá. Grupo de investigación en fitoquímica y farmacognosia de la Universidad Nacional de Colombia (GIFFUN).

Departamento de Química, Universidad Nacional de Colombia, AA 14490, Bogotá, Colombia.

Instituto de Ciencias Naturales, Universidad Nacional de Colombia, Bogotá Colombia.

Author of correspondence: cosorior@unal.edu.co
} 
los compuestos volátiles activos olfativamente del polvo de los frutos tostados del roble se extrajeron por DES y se analizaron por CG-EM y análisis olfativo (CG-O). La caracterización sensorial de esta bebida sustituta de café fue realizada mediante el empleo de QDA. Resultados: se identificaron diecinueve compuestos y se evidenció la presencia de notas de olor como manteca/caramelo, ahumado/tostado y frutal, similares a las encontradas en el café tostado. Los componentes mayoritarios identificados para este sustituto de café fueron cetonas, aldehídos, ácidos alifáticos, alcoholes furánicos y pirazinas. Los compuestos mayoritarios detectados fueron furfural, 5-metil furfural, alcohol furfurílico y 3-hidroxi-2butanona, algunos de ellos relacionados con la descomposición térmica de azúcares. Los atributos de olor caracterizados por QDA fueron similares a los detectados por CG-O, aunque se detectaron algunas notas de sabor desagradable. Conclusiones: los resultados del molecular sensory approach confirmaron que este producto se parece al café; sin embargo el QDA mostró la presencia de un sabor desagradable. Estudios adicionales son necesarios para mejorar la calidad del sabor de este sustituto de café.

Palabras clave: DES; QDA, compuestos volátiles activos olfativamente; cromatografía de gases; química de alimentos.

\section{INTRODUCTION}

The Quercus genus (Oaks), belongs to the family Fagaceae, and is worldwide renowned by its social and economic value, mostly in the wood processing industry $(1,2)$. Their species, which are approximately 400, mainly occurs in the northern hemisphere as big trees, shrubs or small trees, occupying different kinds of habitats (3). In addition to the use of the cortex in the timber industry, the fruits (acorns) from oak have been part of the human diet since ancient times, due to their great nutritional value. Acorns have been used as food resource or as an ingredient for the elaboration of food and beverages. Products from acorns, such as flour, bread, soup, oil, coffee substitute, among others, have been reported elsewhere (4-9). Despite its high nutritional value, a decline in consumption of food and beverage products based on acorns has been evident, but with the development of organic, functional and wild collected food, this condition is currently changing (4, 10-11).

In Colombia, there is only a single oak species, Quercus humboldtii Bonpl. This endemic species, is commonly known as "roble de tierra fría", "roble", "roble blanco", "roble negro" and "encino" and is widely distributed in the Andean region with altitudes ranging between 1600 and 3500 meters above sea level (12-14). Traditionally, wood obtained from Q. humboldtii is used in craft making, wood for barrels, and firewood as well as in the furniture production and leather industry because its high content of tannins (12). However, rural communities from Santander and Cauca States in Colombia, dry the acorns of Q. humboldtii under sunlight, then roast and ground to produce a powder (so called "café roble"), which is used to prepare a hot infusion beverage that is consumed as coffee substitute beverage (15). The use of roasted oak nuts in the elaboration of a coffee substitute is not a new practice and the utilization of Quercus acorns from different species has been reported (5). Local population refers such obtained Q. humboldtii product has similar organoleptic properties to those exhibited by roasted coffee (Coffea arabiga) beans and exhibited a sweet chocolate-like aroma.

Based on this information, the aim of the present work was to characterize the sensory properties of a hot beverage obtained from roasted Q. humboldtii acorns that is consumed as a coffee substitute. Thus, the odour-active volatiles of the powder derived from roasted Quercus humboldtii acorns were identified by using the combination of GC-O (Gas Chromatography coupled to Olfactometry), and GC-MS (Gas Chromatography coupled to Mass Spectrometry); and appearance, odour, and taste of the hot beverage was evaluated by a QDA (Quantitative Descriptive Analysis). With these data the quality of this added-value product could be improved, to achieve a medium-term goal to commercialize it as functional food.

\section{MATERIALS AND METHODS}

\section{Plant material}

The study was carried out on a $500 \mathrm{~g}$ sample of roasted Q. humboldtii acorn powder acquired in the local markets of Suaita (Santander, Colombia). For that purpose, the Q. humboldtii acorns are sun 
dried to extract the kernels, that are uniformed roasted at medium temperature $\left(190-200^{\circ} \mathrm{C}\right)$ and then pulverized to get the powder (15), in an artisan process.

\section{Chemicals}

Diethyl ether, $n$-pentane, and anhydrous sodium sulfate were acquired from Merck (Darmstadt, Germany). All solvents were freshly distilled prior to use. An $n$-Alkane mix $\left(\mathrm{C}_{8}-\mathrm{C}_{26}\right)$ was purchased to Laboratory Dr. Ehrenstorfer GmbH, Augsburg, Germany.

\section{Sample preparation}

A Likens-Nickerson type SDE (Simultaneous steam Distillation-solvent Extraction) apparatus (16) was used to extract volatile compounds of the sample. For the analysis, $200 \mathrm{~g}$ of the sample were dissolved in $500 \mathrm{~mL}$ of distilled-deionized water and loaded in a $2 \mathrm{~L}$ round bottom flask. The extraction was carried out with $320 \mathrm{~mL}$ of $n$-pentane-diethyl ether $(1: 1, v / v)$ during $2.5 \mathrm{~h}$. The extract was dried over $\mathrm{Na}_{2} \mathrm{SO}_{4}$ and concentrated to $1.0 \mathrm{~mL}$ using a Vigreux column.

\section{Analyses of odour-active volatiles by GC-FID and GC-O}

GC-O analyses were performed in a gas chromatograph HP 5890 Series II (HewlettPackard, USA) equipped with FID and operated in split mode $(1: 10$, injected volume, $1 \mu \mathrm{L})$. The injection port was set at $230^{\circ} \mathrm{C}$ and helium was used as carrier gas at $1.0 \mathrm{~mL} / \mathrm{min}$. Two capillary columns, DB-FFAP and DB-5 (each $30 \mathrm{~m} \times 0.32$ $\mathrm{mm}$ i.d., $0.25 \mu \mathrm{m}$ film thickness; J\&W Scientific, Chromatographie-Handel Müller, Fridolfing, Germany, and Restek, USA, respectively) were used for the volatile analyses. The column oven was programmed at $40^{\circ} \mathrm{C}$ for $4 \mathrm{~min}$, followed by an increasing until $180^{\circ} \mathrm{C}$, at $6^{\circ} \mathrm{C} / \mathrm{min}$, then at $12^{\circ} \mathrm{C} /$ min until $230^{\circ} \mathrm{C}$ for the DB-FFAP and $300^{\circ} \mathrm{C}$ for the DB-5, and finally the columns were maintained for $10 \mathrm{~min}$ at the maximum temperatures. The end of the FFAP column was connected to a deactivated Y-shaped glass splitter (Chromatographie Handel Mueller, Fridolfing, Germany), which divides the effluent into two equal parts, one for $\operatorname{FID}\left(230^{\circ} \mathrm{C}\right)$ and the other for heated sniffing port $\left(200^{\circ} \mathrm{C}\right)$ by using deactivated fused silica capillaries of the same length (50 $\mathrm{cm} \times 0.32 \mathrm{~mm}$ i.d.). Sniffing port consisted of a self-made elbow-shaped aluminum tube $(80 \times 5 \mathrm{~mm}$ i.d) where the trained panelists (3) located the odour-active zones of the SDE extracts by GC-O (17).

\section{Gas chromatography-mass spectrometry analyses}

GC-MS (EIMS) analyses of aroma active compounds were carried out on a GC Agilent $7890 \mathrm{~B}$ gas chromatograph coupled to a mass spectrometry 5977A (Agilent Technologies Inc. Wilmington, DE, USA). MS data were recorded between 40-350 $\mathrm{u}$, with an electron energy of $70 \mathrm{eV}$ and processed by Mass Hunter software. Chromatographic conditions were the same that those above-mentioned for GC-FID analyses for FFAP column. Data acquisition was carried out with Qualitative Analysis Software (database NIST/ EPA/NIH Mass Spectral Library 2014 (2.2)).

\section{Identification of odour-active volatiles}

Linear retention indexes (LRI) of the odouractive compounds were calculated by using a mixture of normal paraffin $\left(\mathrm{C}_{8}-\mathrm{C}_{26}\right)$ as external references (18). The identification of volatile compounds was completed by comparison of their retention indexes (in the two columns), mass spectra, and odour notes, with those reported in databases (19), and the abovementioned NIST database.

\section{Sensory analyses: Quantitative Descriptive Analysis}

The appearance, aroma, and taste profile of coffee substitute was evaluated by the sensory panel from the staff of the "Laboratorio de Análisis Sensorial de Alimentos, Universidad de Antioquia (Medellín, Colombia)". It was composed of 10 trained judges (men and women with ages ranging from 25 to $60)$, who were trained in several sessions prior to analysis, in which the sensory relevant attributes of coffee powder were defined and evaluated (20). Roasted Q. humboldtii acorn powder $(5.5 \mathrm{~g})$ was dissolved in $100 \mathrm{~mL}$ of water at $90^{\circ} \mathrm{C}$ and then homogenized. The panelists evaluated the sample at $58^{\circ} \mathrm{C}$, ranking the attributes for appearance (3), odour (16), and taste (14), from ten (10) to zero (0) according to the intensity of each attribute. 


\section{RESULTS}

\section{Odour-active volatiles}

The volatile extract obtained by SDE from powder of roasted oak accorns was analysed by GCFID and GC-O to detect the odour-active volatiles, which were the only identified compounds, according to the well-known molecular sensory approach (17). Thus, nineteen odour-active volatile compounds were identified in the roasted oak acorn beverage (Table 1, Figure 1). Different odour notes were detected, all of them related to the usual notes of coffee (21): acid (acetic, and propanoic acids), buttery/caramel (2,3-pentanedione, hexanal, 3-hydroxy-2-butanone, nonanal, furfural, 2,3-dimethyl-2-cyclopenten-1-one, 5-methyl furfural, butanoic acid, isomaltol, 1-furfuryl pyrrole, and 2-acetyl-1H-pyrrole), smoke/roasted (furfuryl methyl ether, dimethyl pyrazine, 2-ethyl pyrazine, and furfuryl alcohol), and fruity (3-penten-2-one, and benzaldehyde) odour notes. Among them, 2,3-pentanedione, hexanal, dimethyl pyrazine, 2-ethyl pyrazine, acetic acid, furfural, 5-methyl furfural, and butanoic acid have been reported as odorant compounds of roasted coffee $(21,22)$. Furfural, 5-methyl furfural, and furfuryl alcohol were predominant in the SDE extract of roasted oak acorns (Figure 1).

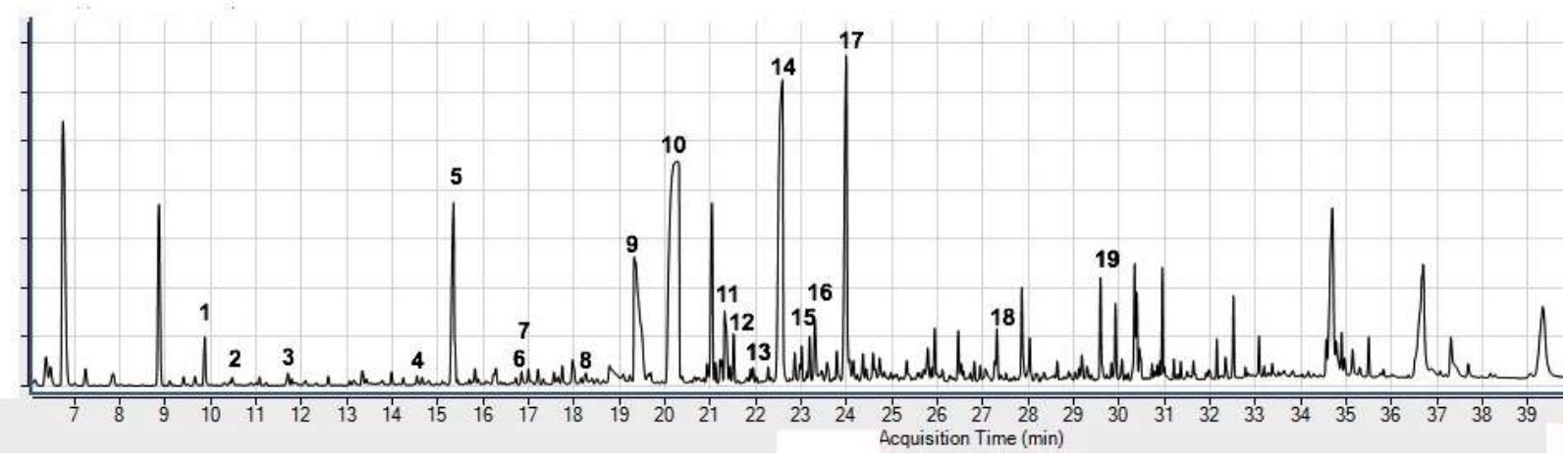

Figure 1. Total ion chromatogram of SDE extract of volatile from roasted oak acorns using FFAP column. The numbers correspond to the compounds in Table 1.

Table 1. Odour-active volatile compounds detected in the SDE extract from coffee substitute obtained from roasted Q. humboldtii acorn powder.

\begin{tabular}{|r|l|l|c|c|c|}
\hline \multirow{2}{*}{ No. Compound } & \multirow{2}{*}{ Odour quality } & \multicolumn{2}{c|}{ RI } & \multirow{2}{*}{$\begin{array}{c}\text { Amount } \\
\text { (Area percentage } \pm \text { SD) }\end{array}$} \\
& & & FFAP column & DB-5 column & $1.43 \pm 0.12$ \\
\hline 1 & $2,3-$-Pentanedione & Sweet, caramel & 1084 & - & $0.27 \pm 0.00$ \\
\hline 3 & Hexanal & Green, fatty & 1104 & - & $0.43 \pm 0.02$ \\
\hline 4 & F-Penten-2-one & Fruity, metallic & 1117 & - & $0.31 \pm 0.03$ \\
\hline 5 & 3-Hydroxy-2-butanone & Coffee & 1268 & 820 & $7.41 \pm 0.02$ \\
\hline 6 & Dimethyl pyrazine & Fatty & 1300 & 711 & $0.60 \pm 0.07$ \\
\hline 7 & 2-Ethyl pyrazine & Roasted & 1321 & - & $0.47 \pm 0.05$ \\
\hline 8 & Nonanal & Coffee, roasted & 1350 & 906 & $0.48 \pm 0.04$ \\
\hline 9 & Acetic acid & Fatty, chocolate & 1408 & - & $11.50 \pm 0.16$ \\
\hline 10 & Furfural & Vinegar & 1428 & - & $30.81 \pm 1.15$ \\
\hline 11 & Propanoic acid & Coffee, sweet & 1498 & - & $2.95 \pm 0.04$ \\
\hline 12 & Benzaldehyde & Rancid, green & 1521 & - & $1.26 \pm 0.07$ \\
\hline 13 & 2,3-Dimethyl-2-cyclopenten-1-one & Floral, sweet & 1596 & - & $0.39 \pm 0.03$ \\
\hline 14 & 5-Methyl furfural & Roasted, caramel & 1611 & 978 & $20.19 \pm 0.35$ \\
\hline 15 & Butanoic acid & Rancid, papaya, fruity & 1614 & 811 & $1.10 \pm 0.06$ \\
\hline 16 & Isomaltol & Caramel, sweet & 1654 & - & $2.17 \pm 0.07$ \\
\hline 17 & Furfuryl alcohol & Roasted, burned & 1665 & 851 & $13.50 \pm 0.39$ \\
\hline 18 & 1-Furfuryl pyrrole & Roasted, sweet & 1869 & - & $1.93 \pm 0.17$ \\
\hline 19 & 2-Acetyl-1H-pyrrole & Roasted, nutty, sweet & 2020 & 1060 & $2.80 \pm 0.16$ \\
\hline
\end{tabular}

-: Not detected; RI: Retention Index; ${ }^{\star}$ : average of odour-active volatiles $(n=2)$. 


\section{Sensory analyses}

The results of QDA are shown in Figure 2. The evaluated attributes were the characteristic of roasted coffee bean powder. The most significant odour notes were: sweet, smoke, NCS (noncentrifugal cane sugar, so called "panela”), caramel, and burned bread, in agreement with the odour notes perceived by GC-O from volatile extract obtained by SDE. As part of QDA, many taste notes were evaluated; thus, bitter, smoke, burned, and astringent taste notes were ranked with the highest scores.

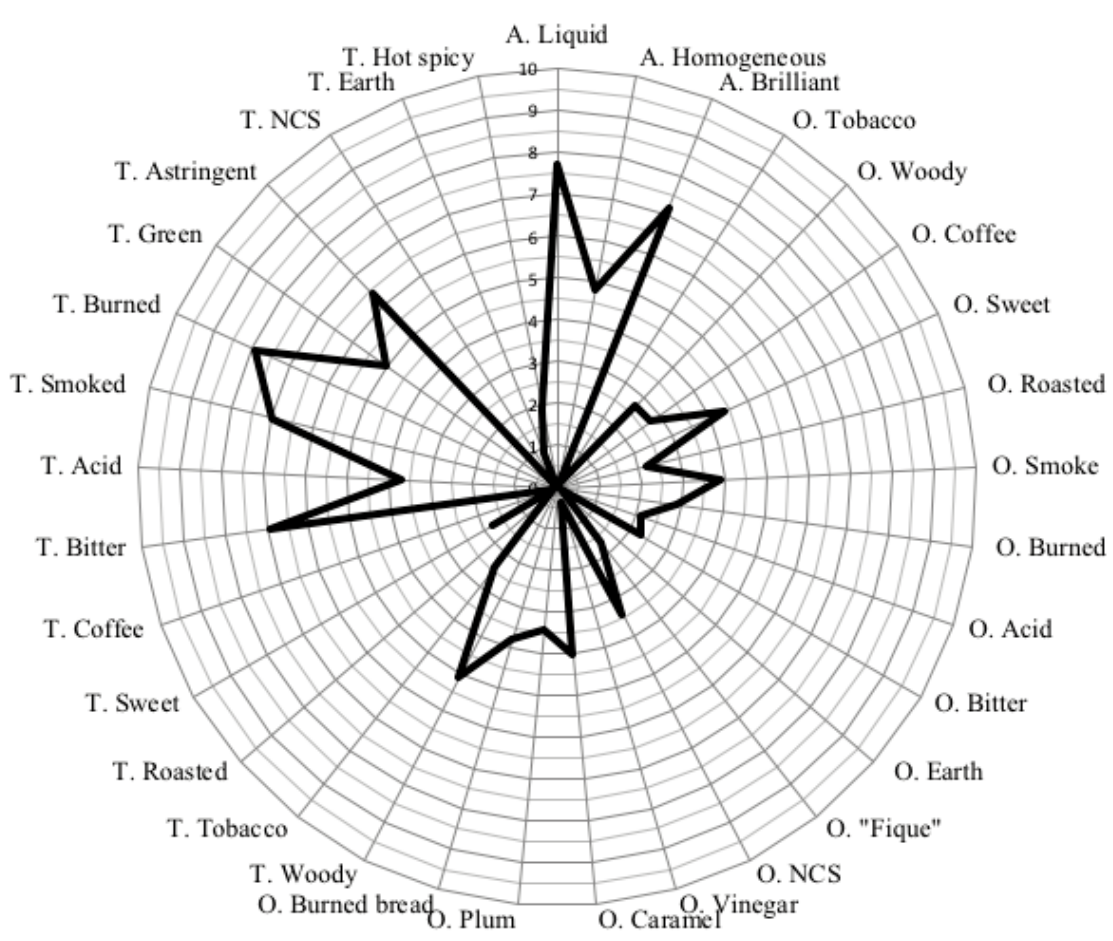

Figure. 2. Sensory evaluation (QDA) results of infusion prepared with roasted oak acorn powder.

\section{DISCUSSION}

SDE technique, that includes the heating of the sample, was chosen to obtain the volatile extract from roasted oak acorn powder because this coffee substitute beverage is consumed after the oak powder is mixed with hot water for a certain time, in a similar way that common coffee is prepared. Among nineteen odour active volatiles, furfural, 5-methyl furfural, and furfuryl alcohol were the major constituents. These volatile compounds are usually produced by sugar thermal breakdown, which is likely to happen during the acorn roasting. It is known that roasting is a process that favors the development of Maillard reaction, lipid thermal oxidation, Strecker degradation, or caramelisation, according to the composition of original material (23). Additionally, the influence of furfuryl compounds in the flavor of oak-aged wines has been studied and is influenced by the wood's origin of barrels (24), however furfuryl alcohol does not have any significance in the aroma of wines, in contrast with the results here obtained for the coffee substitute beverage.

It is important to point out, that the other volatile compounds present in the SDE volatile extract (Figure 1) from roasted oak acorn were not reported in this study because they do not have any influence on the aroma. But their mass spectra showed the presence of many fatty acids, some volatile phenolic compounds, such as, guaiacol and phenol, and aromatics such as, 1, 2, 4-trimethoxy benzene. The phenolic compounds and fatty acids from acorns of other Quercus species (Q. ilex, Q. rotundifolia, and Q. suber) have been identified (25), showing the predominance of oleic, palmitic, and linoleic acids. Some phenolic compounds were also characterized, mainly gallic acid derivatives, suggesting that they are responsible for the antioxidant activity of oak acorns (11). 
The results of sensory analyses are interesting because 2,5 -dimethyl pyrazine, furfural, propanoic acid, and furfuryl alcohol (2-furanmethanol) were also identified as odour-active volatiles in non-centrifugal cane sugar (NCS) beverage (26). Despite odour notes resemble those of coffee, the trained panel concluded that the taste of this coffee substitute is not well equilibrated, because the presence of off-flavors, such as, astringency and burning taste notes. The next step is to characterize phenolic compounds that could be responsible for these undesirable taste notes in order to equilibrate and improve its flavor. Rakić et al, (11) found that roasted oak acorns from Quercus robur contain $14.93 \%$ of polyphenols and $14.06 \%$ of proteins, among other constituents. In that work, the content of biofunctional compounds showed that processing of oak acorns improves their functional properties (antioxidant activity). Despite other food product develop from Quercus acorns have been studied before (4-9), it is important to point out that this is the first study of aroma volatile compounds of this coffee substitute beverage.

\section{CONCLUSIONS}

A coffee substitute beverage from roasted oak acorns was sensory evaluated. The results of molecular sensory approach focused on odour notes, confirmed that this product resembles coffee; however, QDA analyses performed by a trained panel showed the presence of undesirable taste. Despite this fact, this coffee substitute is widely consumed in some regions of Colombia. This is the first approach to evaluate sensory properties of this promising added-value product obtained from oak, with potential to be commercialized as functional food. This coffee substitute exhibits coffee-like sensory properties without having caffeine; however, more sensory studies as well as, the characterization of non-volatile compounds related to taste notes (phenolics and alkaloids) are need in order to improve the taste quality of this coffee substitute.

\section{CONFLICTS OF INTEREST}

The authors declare that there is no any conflict of interest.

\section{ACKNOWLEDGEMENTS}

The authors thank the Universidad Nacional de Colombia, Dirección de Investigaciones-Sede Bogotá for financial support.

\section{AUTHOR'S CONTRIBUTIONS}

LDR, NGB and DPF performed experimental work. ELL and JCML contributed with conception and design of the study. JCML and CO performed the experimental designed, supervised the work at lab, interpreted the data and wrote the manuscript. All the authors have read the final version of the manuscript and approved it.

\section{REFERENCES}

1. Nixon KC. Global and neotropical distribution and diversity of Oak (genus Quercus) and Oak Forests. In: Kappelle M, editor. Ecological Studies, Vol. 185. Ecology and Conservation of Neotropical Montane Oak Forests. Berlin, Heidelberg: Springer-Verlag; 2006. 3-13 p.

2. Löf M, Brunet J, Filyushkina A, Lindbladh M, Skovsgaard JP, Felton A. Management of oak forests: striking a balance between timber production, biodiversity and cultural services. Int. J. Biodivers. Sci. Ecosyst. Serv. Manage. 2016; 12(1-2): 59-73.

3. Xu X, Wang Z, Rahbek C, Sanders NJ, Fang J. Geographical variation in the importance of water and energy for oak diversity. J Biogeogr. 2016 Feb; 43(2): 279-288.

4. Ayerdi M, Echazarreta-Gallego A, de Francisco-Rodríguez S, Hernández HH, Sarasketa-Gartzia I. Acorn cake during the Holocene: experimental reconstruction of its preparation in the western Pyrenees, Iberia. Veget Hist Archaeobot. 2016 Sep; 25(5): 443-457.

5. Bainbridge DA. Acorns as Food. History, use, recipes, and bibliography. [Internet]. Berkeley, USA: Bekeley Electronic Press. 1999 [Updated 13 february of 2014; quoted 2 november 2018]. Available in: https://works.bepress.com/david_a_ bainbridge/17/download/.

6. Korus J, Witczak M, Ziobro R, Juszczak L. The influence of acorn flour on rheological properties of gluten-free dough and physical characteristics of the bread. Eur Food Res Technol. 2015 Jun; 240(6): 1135-1143.

7. Leporatti ML, Corradi L. Ethnopharmacobotanical remarks on the Province of Chieti town (Abruzzo, Central Italy). J Ethnopharmacol. 2001 Jan; 74(1): 17-40.

8. Pinna C. Acorn bread: A traditional food of the past in Sardinia (Italy). J Cult Herit. 2013 Jun; 14(3): S71-S74.

9. Silva S, Costa EM, Borges A, Carvalho AP, Monteiro MJ, Pintado MME. Nutritional characterization of acorn flour (a traditional component of the Mediterranean gastronomical folklore). J Food Meas Charact. 2016 Sept; 10(3): 584-588.

10. Łuczaj L, Pieroni A. Nutritional ethnobotany in Europe: From emergency foods to healthy folk cuisines and contemporary foraging trends. In: Sánchez-Mata MdeC, Tardío J, Editors. Mediterranean Wild Edible Plants. New York, USA: Springer Science+Business Media; 2016. 33-56 p.

11. Rakić S, Povrenović D, Tešević V, Simić M, Maletić R. Oak acorn, polyphenols and antioxidant activity in functional food. J Food Eng. 2006 June; 74(3): 416-423. 
12. Gómez-Restrepo ML, Toro-MurilloJL. Manejo de las Semillas y la Propagación de Diez Especies Forestales del Bosque Andino. Boletín Técnico Biodiversidad; No.1. 1era Edición. Medellín, Colombia: Corporación Autónoma Regional del Centro de Antioquia- CORANTIOQUIA; 2007. 66-71p.

13. Paz PGM. Variabilidad genética del roble común (Quercus humboldtii Bonpl.) en la región del macizo colombiano. Rev Bio Agro. 2012 Jun-Dic; 10(2): 110-116.

14. Rodríguez-Correa H, Oyama K, MacGregor-Fors I, GonzálezRodríguez A. How are oaks distributed in the Neotropics? A perspective from species turnover, areas of endemism, and climatic niches. Int J Plant Sci. 2015 March/April; 176(3): 222-231.

15. Potosí-Gutiérrez A, Villalba-Malaver JC, Arboleda-Pin LY. Non-timber forest products associated oak forest Quercus humboldtii Bonpl in La Vega, Cauca. Rev Bio Agro. 2017 Jul/ Dec; 15(2): 22-29.

16. Likens ST, Nickerson GB. Detection of certain hop oil constituents in brewing products. Proc Am Soc Brewing Chemists. 1964; 22(1): 5-13.

17. Schieberle P. Recent developments in methods form analysis of volatile flavor compounds and their precursors. In: Gaonkar A, editor. Characterization of food: Emerging methods. Amsterdam, The Netherlands: Elsevier; 1995. 403-431 p.

18. De Santana KL, Galvão MdeS, De Jesús MS, Nogueira JP, Narain N. HS-SPME optimization and extraction of volatile compounds from soursop (Annona muricata L.) pulp with emphasis on their characteristic impact compounds. Food Sci. Technol (Campinas). 2017 Apr/Jun; 37(2): 250-260.
19. El-Sayed AM. The Pherobase: Database of pheromones and semiochemicals. [Internet]. Toronto, Canada. 2003 [Updated september 26 of 2017; quoted November 1 of 2018]. Available in: http://www.pherobase.com/.

20. Icontec. Norma Técnica Colombiana, NTC 4883. Análisis sensorial. Café. Metodología para análisis sensorial cuantitativo descriptivo del café. Bogotá: Icontec; 2000.

21. Toci AT, Boldrin MVZ. Coffee beverages and their aroma compounds. In: Grumezescu AM, Holban AM, editors. Natural and artificial flavoring agents and food dyes. Handbook of Food Bioengineering. London, UK: Academic Press; 2018. 397-425 p.

22. Sunarharum WB, Williams DJ, Smyth HE. Complexity of coffee flavor: A compositional and sensory perspective. Food Res Int. 2014 Aug; 62: 315-325.

23. Zhang W, Wang R, Yuan Y, Yang T, Liu S. Changes in volatiles of palm kernel oil before and after kernel roasting. LWT-Food Sci Technol. 2016 Nov; 73: 432-441.

24. Gómez-Plaza E, Pérez-Prieto LJ, Fernández-Fernández JI, López-Roca JM. The effect of successive use of oak barrels on the extraction of oak-related volatile compounds from wine. Int J Food Sci Tech. 2004 Dec; 39(10): 1069-1078.

25. Cantos E, Espín JC, López-Bote C, De la Hoz L, Ordoñez JA, Tomás-Barberán FA. Phenolic compounds and fatty acids from acorns (Quercus spp.), the main dietary constituent of free-ranged Iberian pigs. J Agric Food Chem. 2003 Oct; 51(21): 6248-6255.

26. García JM, Narváez PC, Heredia FJ, Orjuela A, Osorio C. Physicochemical and sensory (aroma and colour) characterisation of a non-centrifugal cane sugar ("panela") beverage. Food Chem. 2017 Aug; 228(1): 7-13. 